\title{
Border Management Framework -Dynamics and Challenges
}

\author{
Shri. K Srinivasan \\ Inspector General (Retd), BSF and Ex IG Consultant (Intelligence) CRPF
}

\section{The Concept of Border}

Though used interchangeably with words like 'boundary' and frontier', the term 'border' has a specific connotation. In simple terms, a 'border' is the official line separating two countries, provinces, or areas that a particular governing body control. In the international arena, borders place the states within a sovereign frame defining the extent of a state's power. Respecting sovereign borders, therefore, is tantamount to recognizing the sovereignty of a particular state. In terms of physicality, borders are generally classified into two: Hard (fenced and guarded); and Soft (regulated but open or unregulated) borders or in other words 'thick' and 'thin' borders.

As, Borders are considered as an outer membrane of a state which protects the territory the border management entails facilitating the legitimate cross-border flows of people and trade while concurrently preventing the entry of persons of goods who/ which pose a threat to the home territories or population. Border management hence has to strike a fine balance between keeping the borders open for the legitimate flow of travel and commerce and closing them to potential threats.

It is imperative that effective border management requires a precise conception of what constitutes a legitimate crossing and what is an irregular crossing and therefore a threat. Almost all countries at present have to grapple with a combination of threats and challenges along their borders, which include illegal, migration, drug and human trafficking, gun running, smuggling of commodities and cross border terrorism. Dealing with such threats apparently, borders signify simultaneous inclusion and exclusion, in the sense of what / who belongs to us and what /who does not.

A well developed and well-guarded borders are generally inviolable and in keeping with the maxim: 'Developed borders are secured borders'. States undertake border development programmes motivated principally for this reason. It is realized that unlike the 'security approach' that is mostly centralized, militarized, and top-down, the 'development approach' is inherently 
decentralized, demilitarized and bottom up. In short the living standards and self- esteem of the border population are given importance as they are considered to be 'Strategic Assets'

\section{Border Data -India with neighbors}

\begin{tabular}{|l|l|}
\hline Country & $\begin{array}{l}\text { Length of land Border } \\
\text { (Kilometers) }\end{array}$ \\
\hline Pakistan & 3323 \\
\hline Afghanistan & 106 \\
\hline China & 3437 \\
\hline Nepal & 1751 \\
\hline Bhutan & 587 \\
\hline Myanmar & 1643 \\
\hline Bangladesh & 4096.7 \\
\hline
\end{tabular}

\section{Border Management-Indian Context}

India has the most difficult task of managing its multi-terrain borders that run through plains, hills, mountains, snow-covered peaks, deserts, riverine territories, jungles and marshes. Indian borders have different climatic conditions, from harsh winters to hot deserts to tropical monsoon. Interestingly, all except five Indian states, share borders with other countries, land or maritime. India's sovereign borders are also characterized as International Border (IB): Line of Control (LoC): Line of Actual Control (LAC): disputed areas: undemarcated areas and open borders. India is afflicted by the lack of fully demarcated borders. As a result, there are border issues and confrontations between India and its neighbours. The Northeast region of India is uniquely placed. It shares 99 per cent of its boundary with other countries making the nation-building process all the more challenging.

The India Pak border is divided into three parts. First is the International Border, also known as the 'Radcliff line' of 2,300 km from Gujarat to the north banks of Chenab in Akhnoor in Jammu, Line of Control (LoC), of $778 \mathrm{~km}$ long from the north banks of Chenab in Jammu to Leh and Actual Ground Position Line (AGPL) of $110 \mathrm{~km}$ long from NJ9842 to Indira Col in the north. The 
India-China border remains to be-disputed whereas India-Nepal, Bhutan, Myanmar and Bangladesh borders are International Borders.

Significantly, the internal security of India is deeply linked to its border security. The borders also see infiltration/exfiltration of militants, human trafficking, drug peddling, smuggling, illegal migration and other unlawful activities. These are some of the challenges faced by Indian borders, both at conventional and non-conventional levels. With this analytical backdrop, the article aims at addressing these principal issues.

\section{Border Management Structure.}

India's border management strategy has four main elements, viz. border guarding (between ports of entry), border regulation (at the point of entry), development of border areas, and bilateral institutional mechanisms to resolve border disputes and iron out conflicts with neighbors.

\section{A) Guarding the Borders}

The first element of India's border management strategy is the physical guarding of the border. Though, Policing had been a state subject, the raison-d'etre of the creation and maintenance of the Border Guarding Forces is that the ultimate responsibility of the Central Government regarding internal security. While external aggression is become more tech oriented, it is an internal security dimension, which is talking the center stage having potential to disintegrate the country.

The State Police, with its limited capabilities, besides jurisdictional limitation, is unable to cope up with the increasing trans-border and trans-national threats, crime etc. Here comes the role of the BSF, SSB and ITBP.

\section{Stakeholders in National Security Matrix}

Based upon the nature of the task, the Central Armed Police Forces (CAPF), earlier known as Central Para Military Forces (CPMF) can broadly be categorized in the following categories,

(a) Border Guarding Forces: Which constitute Border Security Forces (BSF), Sashastra Seema Bal (SSB) and Indo Tibetan Border Police (ITBP)

(b) Internal Security Forces: Which constitute Central Reserve Police Force (CRPF) 
(c) Industrial Security Forces: Which constitute Central Industrial Security Forces(CISF)

(d) Intelligence Agencies: Which include Intelligence Bureau (IB) and Research \& Analysis Wing (R\&AW)

(e) Investigating Agencies: Which include Central Bureau of Investigation (CBI), National Investigation Agency (NIA)

(f) Special Operation Groups: Which include National Security Guards (NSG) and Special Protection Group (SPG) for VVIP Protection

(g) Disaster Management Forces: Like National Disaster Response force (NDRF)

(h) Enforcement Agencies: Which includes Narcotics Control Bureau and Enforcement directorate (ED).

(i) Training and research Institutions: such as National Police Academy, Directorate of co-ordination Police Wireless, Bureau of Police Research and Development, National institute of Criminology and Forensic Science.

\section{B) Regulating the Borders}

The second main element of India's border management strategy is regulation of the cross-border movement of people and goods that take place through designated transit points. These transit points are monitored, at present, by 132 Land Custom Stations (LCSs) located along the country's various borders. With a view to coordinate among various agencies like the Department of Customs, Bureau of Immigration, Narcotics Control Bureau, an experimental project to transform 13 LCSs into Integrated Check Posts (ICPs).

\section{C) Border Area Development Programme (BADP)}

The third main element in India's approach to border management is the development of border areas. India's border areas continue to be plagued by poor accessibility, inadequate infrastructure, depressed economic growth, poverty and a sense of insecurity among the people. All these issues have not only led to the relative isolation of these areas from the rest of the country but have also forced the border population to engage in criminal activities for economic sustenance. The 
development of border areas has therefore been envisaged as an important element in border management. Towards this end, the Border Area Development Programme (BADP) was initiated as early as 1987 to 'meet the special development needs of the people living in remote and inaccessible areas situated near the international border'." The objectives of the programme are:

- To build critical infrastructure in the border areas,

- To generate economic opportunities and

- To instill a sense of security among the border population.

\section{D) Bilateral Institutional Mechanisms}

a) The fact that borders cannot be secured without the active cooperation of neighbours is well known. To facilitate bilateral dialogue on matters of mutual concern regarding border management, India has constituted a system of institutionalized interactions with its neighbours as the fourth element of its approach to border management. These interactions take the form of meetings between home secretaries, between area commanders of border guarding forces, and through the Joint Working Group on Border Management, where issues like arms and drugs smuggling, illegal migration, infiltration, border trade etc. are discussed.

b) Border liaison meetings between the border guarding forces of India and its neighbors take place at national, sectoral and local levels. The idea behind these meetings is to maintain peace and tranquility along the border and resolve local tensions. Similarly, the surveyors general of India and its neighbours meet to discuss the work plan for joint inspection, repairs, restoration and maintenance of boundary pillars on the border."

While a conventional war is becoming a rare phenomenon, for Border Guarding Forces such as BSF, ITBP and SSB, it is a never ending fight in terms of facing hostile terrain, climate, demarcated patches, lack of logistic support and the mindset of the counterpart with variable equations and dispensations besides social isolation from family. 


\section{Instruments of Border Management Application}

Each Border Guarding Force has got a defined charter of Duties, keeping in view the need and the threat perception.

\section{BORDER SECURITY FORCE (BSF):}

History: Till 1965, India borders were guarded by the State Armed Police (SAP) Battalions. The 1965 war in Pakistan had exposed the inadequacy of the State Armed Police to cope up with the external armed aggression, due to which the Government of India contemplated the need for a specialized centrally controlled border security force. As a result the recommendation of the Committee of Secretaries, the Border Security Force (BSF) came into existence on $1^{\text {st }}$ December, 1965

Role: Security of border of India and matters connected therewith.

Task: The task of the BSF are divided as follows:

(a) Peace time :-

i) Promote a sense of security among the people living in the border areas.

ii) Prevent trans-border crimes, unauthorized entry into or exit from the territory of India.

iii) Prevent smuggling and any other illegal activities.

(in the last few years BSF has in addition to their duties ,been deployed for counter insurgency, internal security duties and C.I. Ops in LWE areas)

(b) War Time:

i) Holding ground as the first line of defence and the first responder in the event of external aggression

ii) Protection of vital installations.

iii) Assistance in control of refugees.

iv) Anti-infiltration duties in specified areas.

Ethos: Its ethos is: Any Task, Any Time, Any Where" and the BSF has given blood and sweat to execute its motto "Duty undo Death" now changed into "Jeevan Paryant Kartvya" 
Structure: Raised with the strength of 25 Battalions, today its having 185 Battalions strength (Two lakhs fifty thousand personnel). BSF has got its own Water Wing, deployed in Sir Creek on the West and Sunderban on the East. The Air Wing of BSF caters to the needs other CPO as well. BSF is credited with several support wings such as Artillery, BSF ' $G$ ' Branch, Tear smoke Unit, Central Arms Repair Workshop, National Dog Training School, Central Motor Transport Wing, Etc

Deployment: Known as "Praharis", The Border Security Force is deployed along the Marshy terrain of Rann of Kutch in Gujarat, the desolate desert border of Rajasthan, the plains of Punjab and the hilly and snowy terrain of J\&K. On the western side on Indo -Pak border, On the eastern front, along Indo-Bangladesh border, BSF is also deployed in reverent border of West Bengal, of the hilly and rugged terrain of North-East. The borders are guarded by establishing Border Out Post (BOP) close to the zero line along the borders. BSF is securing the 2,285 Kms of International Borders (IB) of India with Pakistan, 4096.7 Kms of IB with Bangladesh and 237.2 Kms of Line of Control in J\&K, out of the total LoC length of $728 \mathrm{Kms}$.

Key Role: $\quad$ BSF has played a key role in 1971 war (which resulted in formation of Bangladesh) followed by militancy in Punjab, insurgency in NE, militancy in J\&K and now anti- naxal operations. . The role of BSF in Kargil was also significant. It is instrumental in neutralizing toplevel leadership of various militant outfits in J\&K and brought a turnaround in the valley.

BSF has contributed in sending its personnel to Kosovo, Sudan, Kango, Sri Lanka, etc under UN Missions. BSF is the functional face of Indian Foreign policy Mechanism as being part the bilateral talks with the counterpart Border Guarding Forces such as Pak Rangers and Bangladesh Border Guards. It is the Lead Intelligence Agency (LIA) on Indo-Pak and Indo BD border

\section{Challenges}

The concept of border management is undergoing rapid transformation with the increasing acceptance of globalization. Barriers are being lowered. Trade and commerce are bonding people across the international borders. The restrictions along the borders are no longer as stringent as they were in the past which inter-alia requires fine tuning in their tasks.

In India, the challenges of border management become trivial due to factors peculiar to the country. These are: 
- Most of our land borders are artificial boundaries and are not based on natural features like rivers or watersheds.

- There are stretches of un-demarcated land borders.

- There are no sanitized corridors along the borders and there is habitation/ cultivation right up to the zero line.

- The borders are porous and therefore easily negotiable.

While, in a complex situation the one which the country is facing at present, it may be difficult to always avoid over-lapping roles and responsibility the aim should be to make sure that the basic responsibility of the security agency concerned is not overlooked or diluted. The border security force is a unique force with both "Peace time" and "War time" roles. For Bordermen, there is no distinction between a "Peace posting" or Field posting" as to Bordermen "duty till life" is the way of life.

\section{INDO TIBETAN BORDER POLICE (ITBP)}

History: Known as 'Himveers', the Indo-Tibetan Border Police (ITBP) was raised on 24 th October, 1962.

Role \& Task: Vigil on the Northern borders, detection and prevention of border violation, and promotion of the sense of security among the local populace.

(i) To check illegal immigration \& trans-border smuggling/crimes.

(ii) Provide security to sensitive installation and threatened VIPs.

(iii) Security sensitive installation, banks and protected persons.

(iv) Restore and preserve order in any area in the event of disturbance.

(v) New challenging role that has emerged for ITBP is Disaster Management.

Structure: The Force, which started with 04 Battalions in 1962, is now having 49 battalions with a strength of 70,523 manpower. It is headed by Director General. The primary operating units is Battalion with all supported elements.

Deployment: ITBP is deployed from Karakoram Pass in Ladakh to Jachep la in Arunachal Pradesh, covering $3488 \mathrm{Km}$ of mountainous terrain at an altitude ranging from 9,000 Ft to 18,000 $\mathrm{Ft}$ 
Key Role: ITBP is being designated as a First Responder Force in the Himalayas for Disaster management. Besides giving protection to vital installations, VVIP locations, it has also contributed in the UN Peace keeping efforts. It has played a vital role in Punjab, J\&K and Northeast and also provide security during Kailash Manasasarover Yatra.

Challenges: The border post of ITBP are exposed to high velocity winds, snow blizzards avalanches and land-slides besides extreme cold. The threat from the climate is unique. However, the Force provided its tradition and Keeping the spirit and motto "Shourya- Dridatha -Karam

\section{SASHASTRA SEEMA BAL (SSB)}

History: The Special Service Bureau (SSB) was setup in the early 1963 in the wake of India-China conflict of 1962 to build up the morale and capability in the border population against threats of subversion, infiltration and sabotage from across the border. It became a border guarding force in 2001 under the Ministry of Home affairs and was rechristened 'Sashastra Seema Bal' with border guarding responsibilities along the Indo-Nepal and Indo- Bhutan Boarders.

\section{Role \& Task:}

1. To promote sense of security among the people living in the border area.

2. To prevent trans-border crimes and unauthorized entries into or exit from the territory of India

3. To prevent smuggling and other illegal activities.

Ethos: It subscribes to the ETHOS of Service, Security and Brotherhood.

Structure: Presently, the total strength of Force is 79,000 with civilian non-combatized staff strength of 2,700 .

Deployment: Pursuant to the recommendation of the group of Ministers on reforming the national Security System SSB was declared as a Border Guarding force and lead Intelligence agency (LIA) for Indo- Nepal Border (January 2001) and assigned the task of guarding the $1751 \mathrm{Kms}$ long IndoNepal border.

\section{Some Peculiarities of Border and Myths.}

\section{A) Indo-Pak Border}


- The Rann of Kutch border is salt crusted /marshy expanding $80 \mathrm{~km}$ x10 kms

- The Creek Area is shallow and prone to high tide and low tide restricting boat movement

- The shifting Sand dunes/Sand storms in Rajastan often covers the Fencing

- In Punjab/ Jammu border, cultivation is done ahead of fencing

- As per Boundary agreement no defence related construction is allowed from 150 yards from Zero line

\section{B) Indo -BD border}

- Often Fencing gets washed away during rainy season/floods

- Mosquito problem is more lethal than even militants

- In many areas border runs through houses

- Cattle smuggling is a big menace

- Illegal/legal migrant movement for economic reasons affecting the demography.

\section{Response to the challenges}

\section{Western Theatre}

The threats and challenges that India has been facing along its border with Pakistan over the decades. These countermeasures include construction of fences along the border in the 1980s, the implementation of the Border Area Development Programme in 1987 and, more recently, the construction and operationalization of the integrated check posts. These could be listed as:
a) Construction of fences
b) Regulation at the points of entry/exit
c) Development of the border areas
d) Bilateral Institutional Mechanism of Conflict Resolution

Both BSF and Pakistan Rangers meet periodically to settle local issues 


\section{The Eastern Theatre}

The border with Bangladesh traverses a range of natural and cultural landscapes, which pose a challenge to its effective management. The terrain along the border is a mix of hilly and jungle tracks, plains, riverside, and low-lying land. This diverse mix of topographical features makes the border extremely porous. The thick vegetation and steep gradient in the hilly and forested tracks along north Bengal, south Assam, Meghalaya, and Tripura hinder the construction of proper roads, fences, and Border Observation Posts (BOPs).Consequently, insurgent groups misuse these stretches along the border to smuggle arms and drugs and also to crossover to Bangladesh.

During dry seasons, these rivers part into tributaries and throw up stretches of char land, which get inundated during floods. Though inhabited, these lands are weather-bound, and there is an inadequate presence of security forces. These char lands provide shelter to illegal immigrants from Bangladesh and turn into a hub of criminal activities.

The flat and fertile land along the border supports dense human settlements right up to the border. There are more than a hundred villages located right along the zero line, with many houses opening into Bangladesh. The ethnic composition of the people is similar on both sides of the border and it is quite difficult to differentiate between the citizens of India and continue even today. This factor helped migrants from Bangladesh to crossover to India Illegally

\section{Illegal Migration and Cattle Smuggling}

One of the major consequences of a porous border is the easy and illegal crossing of the border. The trend of illegal migration from Bangladesh into India has continued since Independence. Political upheavals, religious persecution demographic pressures, environmental crises, and so on are some of the 'push factors that have contributed to large-scale influx of Bangladeshis into India.' The pull factors that attract migrants from Bangladesh to India are availabity of land and facilities like employment opportunities, medical care education and similar cultural landscapes .However ,it is also a fact that the influx of legal migrant entering with documents and later becoming illegal due overstay/destroying the documents so as to merge with local population in the border regions .According to West Bengal Police Intelligence report between 1972 to 2005 as many as 86,68,123 BD nationals entered India on valid Visa ,but only 74,11,100 BD nationals returned ,meaning $12,57,023 \mathrm{BD}$ nationals are untraceable in India. Taking into account other states, the figure then 
was around 12 million (all legally entered, became illegals subsequently). Though appearing as a normal crime activity, the cattle smuggling from India to Bangladesh is a critical economic irritant coupled with killing of civilians, which the NGOs/BD/Media exploit.

\section{Border Area Development Programme}

Border areas remain inaccessible and underdeveloped due to difficult terrain and lack of facilities like proper roads, educational institutions, and hospitals. The Border Area Development Programme (BADP) in 1987 caters to promote as sense of security' among the border people by implementing welfare and developmental schemes.

\section{Bilateral Institutional Mechanism}

India and Bangladesh have established institutionalized interaction to discuss border management issues through the meetings of home secretaries, the Joint Working Group (JWG), and director general level talks between the BSF and the Border Guards Bangladesh (BGB). It is significant to note that GOI succeeded ii sorting out the Issue of Enclaves and Adverse Positions

India faces several factors hampering effective border management both on Eastern and Western theatre. The Indian Border Management calls for synchronization of technology, infrastructure, and border population that is capable of dealing the geopolitical, social and economic challenges.

\section{What ails the CAPFs in Border Management?}

Broadly, CAPFs suffer from a combination of factors that could be listed as:

- Working Conditions- The jawans of BSF/ITBP in particular are expected to be on duty for 16-18 hours per day consistently due to threat perception and shortage of manpower. Added to this, the troops are expected to take care of their logistic, accounts ,construction aspects by themselves as there exists no dedicated /branch for above administrative commitments

- Psychological Pressures- Due to remoteness, social isolation, lack of social support in his domestic front, makes him depressed /stressed leading to drastic actions by the individual 
- Operational Overload-With increased threat fronts increased with additional deployment sans augmentation of manpower and infrastructure the work pressure on the men gets intense .This is compounded by diversified deployment in riots, strikes, VIP visits, etc

- $\quad$ Lack of focus for Training- With additional commitments and shortage om manpower, training aspects are sidelined. The units do not get time for collective training as well as firing practices. Moreover the training Institutions/Directorates are headed by Deputationists who have no exposure to Border Management, Tactics.

- Modernization Issues- There is no long term perspective planning for Modernization of Equipments, Weapons, Sensors, Communication, Transport etc This is mainly due lack of time and aptitude on the part of the leadership (Deputationists ) who are frequently changed with variant priorities nurtured by them. Further the bureaucratic procedures, which are very cumbersome results in delay in procurement, by which time the store/Equipment becomes obsolete.

- Cadre Management and Leadership- Whereas Deputation was considered necessary at the formative years of the Force, despite long period of more than 55 years, the Forces are headed by Deputationists with no background of Border Management, who often experiment their likes and dislikes ignoring the fundamentals. The Forces are treated as Parking/Resettlement slots .The focus on Operations, Intelligence, and Training diminished and the Cadre Officers are ignored in terms of placement, promotion. There is a deliberate intention to suppress the Cadre Development and Progression as evident from the fact that even the Supreme Court's decision to treat the CAPFs as Organized Services and implement Non Functional Financial Upgradation, was being ignored.

- Degeneration of Regimentation Concept- Due all above developments, the Units, which inculcated the spirit of regimentation in the formative years are witnessing a gradual dilution of Regimental values, ethics and the espirit-de-corp.

\section{What is needed?}

- The Border Guarding Forces need to be under direct control of PMO or a separate Ministry of Border Management to be handled by officers of Border Guarding Forces as MHA is over loaded with multifold organizations and function 
- A Border Management Advisory body on the lines of CLAWS to be created who can study the problems of $\mathrm{BM}$ and Men and suggest measures to improve the Operational and Administrative efficiency.

- To rejuvenate the lower level leadership and regimentation, there is a need to restore the posts of Lance Naik, Naik in the Units, (This was dispensed with after 5th pay Commission).This is necessary to retain Effective Command Structure and also provide promotional avenues to the men

- More Units to be raised so as to spare troops for training purposes

- Welfare facilities in terms of Housing in each State, Canteen Facilities and Ex Servicemen Status will certainly mitigate the dissatisfaction level in the Force.

- Most important, the Forces are allowed to be headed and run by Cadre Officers as it has enough experience, expertise, capability capacity and competence

- Enhanced human capital investment for acquisition of human intelligence is to be given priority

- Exposure of Cadre Officers to contemporary training needs including courses

- Active involvement of State Government's machinery in Border Security mechanism

- Allotment of NDC course slots exclusively for Cadre Officers followed by enhanced interaction with Army.

- Issue of Smart National Identity Card to the border population and Temporary Work Permit for BD Nationals on Eastern Border with tracking mechanism. (We must realize that influx of BD migrants cannot be stopped because of "Lebensraum Effect")

- Last but not the least, Awareness Scheme on BM factor in National Security Matrix to the students at University level.

\section{Conclusion}

Suffice to say, that, having metamorphosed from a mere Border Policing task to a comprehensive narrative of Border Management Strategy with diversified role, BM becomes a core ingredient in Strategic Analysis of International Relations and internal political Dynamics of the nations with whom India is engaged with. 